\title{
HUBUNGAN ANTARA PENGETAHUAN GIZI SEIMBANG, CITRA TUBUH, TINGKAT KECUKUPAN ENERGI DAN ZAT GIZI MAKRO DENGAN STATUS GIZI PADA SISWA
}

\section{The Relationship Between Balanced Nutrition Knowledge, Body Images, Sufficiency Level Of Energy and Macro Nutrition With Nutritional Status}

\author{
Rika Fitriani $^{1}$, Lintang Purwara Dewanti ${ }^{2}$, Mury Kuswari ${ }^{3}$, Nazhif Gifari ${ }^{4}$, Yulia Wahyuni ${ }^{5}$ \\ Program Studi Gizi, Fakultas Ilmu-Ilmu Kesehatan, Universitas Esa Unggul \\ e-mail: ${ }^{1}$ rikafitriani42@gmail.com \\ e-mail: ${ }^{2}$ lintangpurwara@esaunggul.ac.id
}

\begin{abstract}
Abstrak
Permasalahan gizi yang sering dihadapi oleh remaja adalah masalah gizi ganda, yaitu gizi kurang dan gizi lebih. Status gizi seseorang dapat ditentukan oleh faktor gizi internal dan eksternal. Pengetahuan gizi, citra tubuh, tingkat kecukupan energi dan zat gizi makro merupakan faktor-faktor yang berkesinambungan mempengaruhi status gizi. Penelitian ini bertujuan untuk mengetahui hubungan antara pengetahuan gizi seimbang, citra tubuh, tingkat kecukupan energi dan zat gizi makro dengan status gizi pada siswa SMA Negeri 86 Jakarta. Jenis penelitian ini menggunakan metode analitik deskriptif. Desain penelitian yang digunakan cross sectional, teknik pengambilan sampel proportionate stratified random sampling sebanyak 91 orang. Hasil penelitian menunjukkan adanya hubungan signifikan antara pengetahuan gizi seimbang $(\mathrm{p}=0,0001)$, citra tubuh $(\mathrm{p}=0,0001)$, tingkat kecukupan energi $(\mathrm{p}=0,0001)$, tingkat kecukupan lemak $(\mathrm{p}=0,019)$, tingkat kecukupan karbohidrat $(\mathrm{p}=0,044)$ dengan status gizi siswa. disimpulkan bahwa terdapat hubungan antara pengetahuan gizi seimbang, citra tubuh, tingkat kecukupan energi dan zat gizi makro, dan citra tubuh dengan status gizi siswa SMA Negeri 86 Jakarta. Disarankan perlu adanya penyuluhan mengenai gizi seimbang, pemantauan status gizi remaja di sekolah, serta diharapkan siswa agar lebih memperhatikan asupan dan pola makannya.
\end{abstract}

Kata Kunci : Pengetahuan Gizi ; Citra Tubuh ; Zat Gizi Makro ; Status Gizi.

\begin{abstract}
Nutrition problems that are often faced by adolescents are double burden problems, namely thinness and overweight. A person's nutritional status can be determined by internal and external nutritional factors. Knowledge of nutrition, body images, sufficiency level of energy and macro nutrient are continuous factors that influence nutritional status. This research aims to knowing the relationship between knowledge of balanced nutrition, body images, sufficiency level of energy and macro nutrients with nutritional status in students of 86 Jakarta Senior High School. This type of research uses descriptive analytic methods. The research design used was cross sectional. Sampling in this study using proportionate stratified random sampling technique. The sample in this study amounted to 91 people. The result showed a significant relationship between knowledge of balanced nutrition $(p=0,0001)$, body image $(p=0,0001)$, the level of energy sufficiency $(p=0,0001)$, the level of fat sufficiency $(p=0,019)$, the level of carbohydrate adequacy $(p=0,044)$ with the nutritional status of students. Based on this study it can be concluded that there is a relationship between knowledge of balanced nutrition, the level of energy sufficiency and macro nutrients (fats and carbohydrates), and body image with the nutritional status of students at 86 Jakarta Senior High School. Therefore, there is a need for counseling about balanced nutrition, monitoring the nutritional status of adolescents in schools, and it is hoped that students will pay more attention to their intake and diet.
\end{abstract}

Keywords:Nutrition Knowledge ; Body Image; Macro Nutrition ; Nutritional Status 


\section{Gorontalo Journal Health and Science Community}

Vol :4, No.1,April 2020

\section{PENDAHULUAN}

Masa remaja adalah masa transisi dari anak-anak menuju ke dewasa, biasanya antara 10 sampai 19 tahun (1). Masa ini merupakan masa terpenting di dalam kehidupan, dimana terjadi pertumbuhan dan perubahan biologis diantaranya pematangan seksual, peningkatan berat badan dan tinggi badan. Kecepatan pertumbuhan fisik masa ini adalah kedua tercepat setelah masa bayi, sebanyak 20\% tinggi badan (TB) dan 50\% berat badan (BB) dicapai selama periode ini. Oleh sebab itu, diperlukan asupan gizi yang cukup untuk menjamin pertumbuhan yang optimal (2).

Masalah gizi sangat rentan terjadi pada remaja dikarenakan adanya berbagai pengaruh dari dalam maupun luar yang dapat dengan mudah langsung mengikuti.Perubahan fisik ditandai dengan pertumbuhan badan yang pesat dan matangnya organ reproduksi. Perubahan ukuran tubuh dapat menyebabkan remaja memiliki citra tubuh dan perubahan perilaku makan (3). Perubahan perilaku makan ini mengarah kepada perilaku makan sehat atau perilaku makan tidak sehat yang mungkin membawa dampak negatif salah satunya yaitu tidak seimbangnya asupan gizi yang masuk ke dalam tubuh dengan kebutuhan gizi remaja (4).

Permasalahan gizi yang sering dihadapi oleh remaja adalah masalah gizi ganda (double burden), yaitu gizi kurang dan gizi lebih. Kekurangan gizi pada remaja dapat berakibat menurunnya daya tahan tubuh sehingga mudah terserang suatu penyakit, menghambat pembentukan otot pada masa pertumbuhan, kurangnya tingkat intelegensi (kecerdasan), khususnya pada remaja putri dapat mempengaruhi siklus menstruasi dan produksivitas yang rendah akan mempengaruhi kualitas hidup (5). Status gizi lebih berupa overweight dan obesitas yang dialami remaja memiliki manifestasi klinis di masa dewasa. Remaja yang overweight atau obesitas, akan berisiko besar terkena penyakit kardiovaskuler yang berpotensi menjadi penyakit jantung koroner dan stroke, serta kanker (6). Berdasarkan hasil dari Riset Kesehatan Dasar (Riskesdas) pada tahun 2018, menunjukkan bahwa prevalensi kurus remaja secara nasional pada umur 16-18 tahun sebesar $8,1 \%$ (1,4\% sangat kurus dan $6,7 \%$ kurus). Sedangkan prevalensi gemuk remaja secara nasional pada umur 16-18 tahun sebesar $13,5 \%$ (9,5\% gemuk dan $4,0 \%$ obesitas) (7).

Status gizi seseorang dapat ditentukan oleh faktor gizi internal dan eksternal (8).Faktor yang menjadi dasar pemenuhan tingkat kebutuhan gizi seseorang disebut faktor gizi internal seperti umur, jenis kelamin, dan aktivitas.Faktor yang berpengaruh di luar diri seseorang disebut faktor gizi eksternal yaitu konsumsi makanan.Selain itu, ketidakpuasan citra tubuh (Body Image dissatisfaction) ditemukan sebagai konsekuensi sosial dan salah satu faktor risiko dari malnutrisi (9).Ketidakpuasan terhadap tubuh lebih banyak dialami oleh remaja putri dibanding remaja putra. Hal tersebut mungkin terjadi pada remaja putri saat pubertas seringkali terjadi penambahan lemak pada tubuhnya, sedangkan pada remaja putra merasa puas karena terjadi peningkatan massa otot (10).

Hasil penelitian menunjukkan sebesar 53,3\% remaja putri yang memiliki citra tubuh negatif memiliki status gizi normal (11). Hasil penelitian lain juga menunjukkan responden dengan citra tubuh tidak puas lebih banyak pada remaja yang memiliki status gizi lebih yaitu 


\title{
Gorontalo Journal Health and Science Community
}

\author{
Vol :4, No.1,April 2020
}

sebesar $84,8 \%$ dan responden dengan citra tubuh tidak puas juga banyak pada remaja yang memiliki status gizi kurus yaitu sebesar $18,8 \%$ (12). Remaja yang memiliki ketidakpuasan terhadap tubuhnya, untuk mencapai bentuk tubuh yang diinginkan cenderung memilih untuk mengurangi konsumsi hariannya dibanding mengikuti pola makan sehat seperti lebih banyak konsumsi buah dan sayur.Studi tersebut juga menunjukkan hasil yang serupa yaitu adanya hubungan antara Body Image dengan konsumsi pangan (13).

Ketidakseimbangan antara asupan energi dan zat gizi lainnya dengan kebutuhan gizi memengaruhi status gizi seseorang. Hasil penelitian menunjukkan bahwa remaja dengan asupan energi berlebih sebesar $95,0 \%$, asupan protein berlebih sebesar $75,0 \%$, asupan lemak berlebih sebesar $85,7 \%$ memiliki status gizi lebih (12). Hasil penelitian lain juga menunjukkan bahwa sebesar 40,4\% remaja memiliki status gizi kurang karena hanya mengonsumsi kurang dari 3 porsi bahan makanan sumber karbohidrat, protein hewani serta nabati per hari (14).

Pengetahuan gizi juga dinilai menjadi faktor yang paling penting mempengaruhi status gizi remaja. Tingkat pengetahuan gizi seseorang mempengaruhi sikap dan perilaku dalam memilih makanan yang pada akhirnya akan berpengaruh terhadap keadaan gizi seseorang. Semakin tinggi tingkat pengetahuan seseorang diharapkan semakin baik pula keadaan gizinya (2).Pengetahuan gizi, asupan zat gizi, dan citra tubuh merupakan faktor-faktor yang berkesinambungan mempengaruhi status gizi. Tingkat pengetahuan gizi yang baik dapat mengubah persepsi negatif remaja terhadap bentuk tubuhnya, dimana mereka akan lebih memperhatikan asupan makanan yang bergizi seimbang untuk tubuh mereka dan berpikir ulang ketika melakukan diet ketat, sehingga persepsi negatif tentang citra tubuhnya tidak akan menjadi penghalang bagi mereka untuk tetap mendapatkan asupan gizi yang baik dan cukup dan menghasilkan keadaan dan status gizi normal (15).

Berdasarkan uraian di atas, maka tujuan penelitian ini untuk mengetahui hubungan antara pengetahuan gizi seimbang, citra tubuh, tingkat kecukupan energi dan zat gizi makro dengan status gizi pada siswa SMA Negeri 86 Jakarta.

\section{METODE}

\subsection{Lokasi dan Waktu Penelitian}

Penelitian ini dilakukan di SMA Negeri 86 Jakarta di Jalan Bintaro Permai IV No.36 Kelurahan Bintaro, Kecamatan Pesanggrahan, Jakarta Selatan.Penelitian ini dilakukan pada bulan Juni 2019 sampai dengan Januari 2020.

\subsection{Desain dan Variabel Penelitian}

Jenis penelitian ini menggunakan metode analitik deskriptif. Desain penelitian yang digunakan adalah cross sectional (potong lintang), yaitu dalam hal ini variabel yang diteliti secara bersamaan dalam satu waktu.Variabel independen meliputi karakteristik siswa (jenis kelamin dan umur), pengetahuan gizi, citra tubuh, tingkat kecukupan energi dan zat gizi makro (protein, lemak, dan karbohidrat). Sedangkan untuk variabel dependen adalah status gizi.

\subsection{Populasi dan Sampel}

Populasi dari penelitian ini adalah seluruh siswa kelas XI dan XII yang bersekolah di SMA Negeri 86 Jakarta Selatan yaitu sebanyak 432 orang. Sampel penelitian ini berjumlah 91 orang, dengan memenuhi kriteria sampel penelitian, yaitu : Remaja usia 16-18 tahun yang ada di 
kelas XI dan XII SMA Negeri 86 Jakarta; Remaja dengan jenis kelamin laki-laki dan perempuan; Bersedia mengikuti seluruh rangkaian penelitian hingga selesai. Pengambilan sampel pada penelitian ini menggunakan teknik proportionate stratified random sampling.

\subsection{Pengumpulan Data}

Data primer, meliputi : Data karakteristik sampel melalui angket identitas pribadi; Data pengetahuan gizi siswa diperoleh melalui angket yang berisi pertanyaan sebanyak 30 pertanyaan mengenai 10 pesan gizi seimbang; Data tingkat kecukupan zat gizi makro siswa diperoleh melalui alat bantu formulir food recall selama $2 \times 24$ jam; Data citra tubuh siswa diperoleh melalui angket BSQ (Body Shape Questioner) sebanyak 34 pertanyaan yang berisi tentang persepsi terhadap bagian tubuh; Data status gizi siswa diperoleh melalui pengukuran antropometri, meliputi pengukuran Berat Badan (BB) menggunakan timbangan injak digital merek Camry dengan ketelitian $0,1 \quad \mathrm{~kg}$, dan pengukuran Tinggi Badan (TB) menggunakan microtoise merek GEA SH-2A dengan ketelitian $0,1 \mathrm{~cm}$. Data sekunder mengenai gambaran sekolah SMA Negeri 86 Jakarta meliputi lokasi sekolah, luas bangunan, jumlah tenaga pengajar, jumlah siswa, fasilitas sekolah, dan sebagainya.

\subsection{Analisis Data}

Analisis dilakukan dengan program SPSS 17, Analisis univariat dilakukan untuk mengidentifikasi karakteristik responden. Analisis bivariat dengan uji chi-square dengan nilai $p$-value $<0,05$. Penelitian ini sudah lulus kaji etik dari Universitas Esa Unggul, dengan nomor 0520-19.511/DPKE-KEP/FINALEA/UEU/XI/2019.

\section{HASIL DAN PEMBAHASAN}

\subsection{Analisis Univariat}

Analisis univariat pada penelitian ini menggambarkan distribusi frekuensi dari masing-masing variabel yang diteliti, baik variabel dependen maupun variabel independen pada siswa/i SMA Negeri 86 Jakarta. Hasil univariat disajikan pada tabel 1.

Tabel 1. Distribusi Frekuensi Responden

\begin{tabular}{|c|c|c|}
\hline \multirow{2}{*}{ Variabel } & \multicolumn{2}{|c|}{ Jumlah } \\
\hline & $\mathbf{n}$ & $\%$ \\
\hline \multicolumn{3}{|l|}{ Jenis Kelamin } \\
\hline Laki-Laki & 43 & 47,3 \\
\hline Perempuan & 48 & 52,7 \\
\hline \multicolumn{3}{|l|}{ Status Gizi } \\
\hline Obesitas & 9 & 9,9 \\
\hline Gizi Lebih & 32 & 35,2 \\
\hline Gizi Normal & 50 & 54,9 \\
\hline \multicolumn{3}{|c|}{ Pengetahuan Gizi Seimbang } \\
\hline Kurang & 37 & 40,7 \\
\hline Baik & 54 & 59,3 \\
\hline \multicolumn{3}{|l|}{ Citra Tubuh } \\
\hline Negatif & 30 & 33,0 \\
\hline Positif & 61 & 67,0 \\
\hline \multicolumn{3}{|c|}{ Tingkat Kecukupan Energi } \\
\hline Lebih & 35 & 38,5 \\
\hline Cukup & 48 & 52,7 \\
\hline Kurang & 8 & 8,8 \\
\hline \multicolumn{3}{|c|}{ Tingkat Kecukupan Protein } \\
\hline Lebih & 40 & 44,0 \\
\hline Cukup & 35 & 38,5 \\
\hline Kurang & 16 & 17,5 \\
\hline \multicolumn{3}{|c|}{ Tingkat Kecukupan Lemak } \\
\hline Lebih & 41 & 45,0 \\
\hline Cukup & 38 & 41,8 \\
\hline Kurang & 12 & 13,2 \\
\hline \multicolumn{3}{|c|}{ Tingkat Kecukupan Karbohidrat } \\
\hline Lebih & 22 & 24,2 \\
\hline Cukup & 50 & 54,9 \\
\hline Kurang & 19 & 20,9 \\
\hline
\end{tabular}

bahwa sebagian besar responden dalam penelitian ini berjenis kelamin perempuan $(52,7 \%)$, sebagian besar responden memiliki status gizi normal $(54,9 \%)$, namun hampir $2 / 5$ responden memiliki status gizi lebih dan obesitas $(45,1 \%)$, sebagian besar responden memiliki tingkat pengetahuan gizi seimbang yang baik $(59,3 \%)$, sebagian besar responden memiliki citra tubuh positif $(67,0 \%)$, sebagian besar responden memiliki tingkat kecukupan energi yang cukup $(52,7 \%)$, sebagian besar responden memiliki tingkat kecukupan protein lebih $(44,0 \%)$, sebagian besar responden memiliki tingkat kecukupan lemak yang lebih $(45,0 \%)$, sebagian besar responden memiliki 


\section{Gorontalo Journal Health and Science Community}

Vol :4, No.1,April 2020

tingkat kecukupan karbohidrat yang cukup $(54,9 \%)$.

\subsection{Analisis Bivariat}

Analisis bivariat pada penelitian ini untuk mengukur seberapa besar kemaknaan hubungan antara variabel independen dengan variabel dependen secara statistik. Berdasarkan uji Chi-Square, dikatakan ada hubungan yang bermakna antar variabel jika nilai $p$-value $<0,05$, dan tidak ada hubungan yang bermakna antar variabel jika nilai $p$ value $\geq 0,05$. Hasil analisis bivariat disajikan pada tabel 2 .

Tabel 2. Hubungan antara Pengetahuan Gizi

Seimbang, Citra Tubuh, Tingkat Kecukupan Energi dan Zat Gizi Makro dengan Status Gizi Pada Siswa SMA Negeri 86 Jakarta

\begin{tabular}{|c|c|c|c|c|c|}
\hline \multirow[b]{2}{*}{ Variabel } & \multicolumn{2}{|c|}{ Status Gizi (IMT/U) } & \multirow[b]{2}{*}{ Total } & \multirow{2}{*}{$\begin{array}{c}\text { P- } \\
\text { Value }\end{array}$} & \multirow{2}{*}{$\begin{array}{c}\text { OR } \\
(95 \% \mathrm{CI})\end{array}$} \\
\hline & $\begin{array}{c}\text { Gizi } \\
\text { Lebih }\end{array}$ & Gizi Normal & & & \\
\hline \multicolumn{6}{|c|}{ Tingkat Pengetahuan Gizi Seimbang } \\
\hline Kurang & $33(89,2)$ & $4(10,8)$ & $37(100)$ & \multirow{2}{*}{$0,0001^{*}$} & 47,438 \\
\hline Baik & $8(14,8)$ & $46(85,2)$ & $54(100)$ & & $(13,17-170,75)$ \\
\hline \multicolumn{6}{|c|}{ Tingkat Kecukupan Energi } \\
\hline Lebih & $31(88,6)$ & $4(11,4)$ & $35(100)$ & \multirow{2}{*}{$0,0001 *$} & 35,650 \\
\hline Tidak Lebih & $10(17,9)$ & $46(82,1)$ & $56(100)$ & & $(10,25-123,90)$ \\
\hline \multicolumn{6}{|c|}{ Tingkat Kecukupan Protein } \\
\hline Lebih & $22(55,0)$ & $18(45,0)$ & $40(100)$ & \multirow{2}{*}{0,091} & 2,058 \\
\hline Tidak Lebih & $19(37,3)$ & $32(62,7)$ & $51(100)$ & & $(0,88-4,78)$ \\
\hline \multicolumn{6}{|c|}{ Tingkat Kecukupan Lemak } \\
\hline Lebih & $24(58,5)$ & $17(41,5)$ & $41(100)$ & \multirow{2}{*}{$0,019 *$} & 2,740 \\
\hline Tidak Lebih & $17(34,0)$ & $33(66,0)$ & $50(100)$ & & $(1,16-6,43)$ \\
\hline \multicolumn{6}{|c|}{ Tingkat Kecukupan Karbohidrat } \\
\hline Lebih & $14(63,6)$ & $8(36,4)$ & $22(100)$ & \multirow{2}{*}{$0,044 *$} & 2,722 \\
\hline Tidak Lebih & $27(39,1)$ & $42(60,9)$ & $69(100)$ & & $(1,00-7,35)$ \\
\hline \multicolumn{6}{|l|}{ Citra Tubuh } \\
\hline Negatif & $27(90,0)$ & $3(10,0)$ & $30(100)$ & \multirow{2}{*}{$0,0001^{*}$} & 30,214 \\
\hline Positif & $14(23,0)$ & $47(77,0)$ & $61(100)$ & & $(7,96-114,6)$ \\
\hline
\end{tabular}

Sumber : Data primer 2019

Keterangan : Data disajikan dalam bentuk $(\%) *$ Signifikan $\quad(\mathrm{p}<0,05)$ 


\title{
Gorontalo Journal Health and Science Community
}

\author{
Vol :4, No.1,April 2020
}

Seorang remaja dikatakan gizi lebih apabila $\mathrm{z}$-score IMT/U >1SD sampai dengan 2 SD. Apabila seorang remaja memiliki z-score IMT/U >2SD maka dikategorikan remaja tersebut obesitas (16). Berdasarkan hasil penelitian diketahui bahwa sebagian besar siswa SMA Negeri 86 Jakarta memiliki status gizi normal $(54,9 \%)$, namun masih terdapat status gizi berlebih (gizi lebih 35,2\% dan obesitas 9,9\%). Secara nasional prevalensi kegemukan pada kelompok usia 16-18 tahun adalah $13,5 \%$ (7). Sedangkan prevalensi kegemukan pada kelompok usia 15-19 tahun untuk provinsi DKI Jakarta adalah 13,7\% (14). Hasil penelitian ini menunjukkan bahwa prevalensi status gizi di SMA Negeri 86 Jakarta lebih tinggi bila dibandingkan dengan prevalensi status gizi lebih di Provinsi DKI Jakarta dan Nasional.

Sebanyak $(89,2 \%)$ siswa yang tingkat pengetahuan gizi seimbang yang kurang memiliki status gizi lebih. Hasil uji ChiSquare menunjukkan nilai $\mathrm{p}$-value $=0,0001$ $(\mathrm{p}<0,05)$, yang berarti bahwa Ada hubungan antara tingkat pengetahuan gizi seimbang dengan status gizi siswa SMA Negeri 86 Jakarta. Kemudian, diperoleh nilai $\mathrm{OR}=47,438$ yang berarti bahwa responden yang memiliki tingkat pengetahuan gizi seimbang kurang, lebih beresiko 47,438 kali lipat mengalami status gizi lebih. Sebagian besar responden $(59,3 \%)$ cukup paham mengenai pengetahuan gizi yang benar dan sesuai, tetapi mereka tidak banyak menerapkan informasi yang telah didapat dikarenakan kebiasaan responden yang sedikit sulit diubah. Pengetahuan yang kurang baik pada masyarakat dapat disebabkan karena kurangnya penyuluhan gizi atau sosialisasi mengenai pengetahuan gizi seimbang dan kurangnya kesadaran terhadap gizi. Pengetahuan gizi seseorang berpengaruh terhadap sikap dan perilaku dalam pemilihan makanan yang akhirnya akan berpengaruh pada keadaan gizi individu. Semakin tinggi pengetahuan gizi seseorang diharapkan semakin baik pula keadaan gizinya (17).Hasil penelitian ini sejalan dengan penelitian Syahrir (2013), yang menyatakan bahwa pengetahuan tentang gizi seimbang juga dapat menjadi salah satu faktor yang mempengaruhi status gizi remaja. Dalam penelitiannya yang dilakukan di SMA Islam Athirah Kota Makassar tersebut menunjukkan sebanyak $40 \%$ responden yang memiliki pengetahuan gizi rendah memiliki status gizi kurang dan gizi lebih(18).

Sebanyak $(88,6 \%)$ siswa yang tingkat kecukupan energi yang lebih memiliki status gizi lebih. Hasil uji Chi-Square menunjukkan nilai $p$-value $=0,0001 \quad(p<0,05)$, yang berarti bahwa Ada hubungan antara tingkat kecukupan energi dengan status gizi siswa SMA Negeri 86 Jakarta. Kemudian, diperoleh nilai $\mathrm{OR}=35,650$ yang berarti bahwa responden yang memiliki tingkat kecukupan energi yang lebih, berpotensi 35,650 kali lipat mengalami status gizi lebih.

Tingkat kecukupan energi dan zat gizi makro didapatkan dari wawancara 24-hour food recall selama 2 hari tidak berturut-turut. Energi merupakan salah satu hasil metaboliseme karbohidrat, protein dan lemak.Energi berfungsi sebagai zat tenaga untuk metabolisme, pertumbuhan, pengaturan suhu dan kegiatan fisik.Energi merupakan zat yang sangat esensial bagi manusia dalam menjalankan metabolism basal, melakukan aktivitas, pertumbuhan dan pengaturan suhu.Kecepatan pertumbuhan fisik pada masa remaja merupakan fase tercepat kedua setelah pertumbuhan bayi, sehingga dibutuhkan asupan energi yang cukup pada remaja (19). Hasil penelitian ini sejalan dengan penelitian yang dilakukan oleh Muchlisa (2013) mengatakan bahwa terdapat hubungan yang signifikan antara tingkat kecukupan energi dengan status gizi(20). Ketidakseimbangan antara asupan energi dengan kebutuhan gizi memengaruhi status gizi seseorang.Ketidakseimbangan positif terjadi apabila asupan energi lebih besar dari pada kebutuhan sehingga mengakibatkan kelebihan berat badan atau gizi lebih. Kelebihan energi akan disintesis menjadi lemak dalam tubuh, sedangkan lemak yang telah tersimpan dalam tubuh tidak terpakai. Akibatnya, penimbunan 


\section{Gorontalo Journal Health and Science Community}

Vol :4, No.1,April 2020

lemak terus terjadi dan mengakibatkan kegemukan atau obesitas (21).

Sebanyak $(55,0 \%)$ siswa yang tingkat kecukupan protein yang lebih memiliki status gizi lebih. Hasil uji Chi-Square menunjukkan nilai $p$-value $=0,091 \quad(p>0,05)$, yang berarti bahwa Tidak Ada hubungan antara tingkat kecukupan protein dengan status gizi siswa SMA Negeri 86 Jakarta. Kecukupan protein responden tercukupi dan lebih dikarenakan sumbangan dari sumber bahan makanan lainnya yang juga mengandung tinggi lemak, dan karbohidrat.Hasil penelitian ini sejalan dengan penelitian Atika (2015) menunjukkan bahwa tidak terdapat hubungan antara asupan protein dengan status gizi(22).Senada dengan hal tersebut, penelitian yang dilakukan Rinanti (2014) juga menyatakan bahwa tidak ada hubungan antara tingkat kecukupan protein dengan status gizi(23). Menurut Almatsier (2009), sumber protein yang baik didapatkan dari bahan makanan hewani, baik dalam jumlah maupun mutunya seperti telur, susu, daging, unggas, ikan, dan kerang. Sumber protein nabati adalah kacang kedelai yang sering dihasilkan produk olahan seperti tempe dan tahu. Padi-padian serta produk hasil olahannya relatif rendah protein, akan tetapi karena dikonsumsi dalam jumlah yang banyak, maka dapat memberi sumbangan besar terhadap konsumsi protein.

Berdasarkan pengamatan hasil food recall responden, makanan yang mengandung protein yang setiap hari dikonsumsi oleh sebagian besar responden adalah tahu, tempe, telur, ayam. Porsi makan responden terhadap makanan yang mengandung protein dapat dikatakan cukup, dalam 1 kali makan responden dapat mengkonsumsi tempe atau tahu, ayam, telur, dan nasi setiap harinya. Terdapat responden yang mengkonsumsi 300 gr nasi dalam 1 kali makan, responden mengonsumsi gorengan sebanyak 3 potong dalam 1 kali makan, sehingga dapat disimpulkan bahwa tingkat kecukupan protein yang lebih didapatkan dari sumbangan makanan lain yang tinggi energi, tinggi lemak, dan karbohidrat. Berdasarkan hal tersebut, responden dengan kondisi kurang asupan protein atau tercukupi tetapi memiliki status gizi yang gemuk dapat terjadi karena kebutuhan energinya tercukupi dari karbohidrat dan lemak tetapi proteinnya kurang.Responden tersebut memiliki kecukupan energi yang lebih besar daripada aktivitas yang dilakukan, sehingga responden dapat mengalami kegemukan.

Berdasarkan hasil penelitian ini juga menujukkan sebesar $(45,0 \%)$ remaja dengan tingkat kecukupan protein yang lebih memiliki status gizi normal. Hal tersebut menunjukkan bahwa tingkat kecukupan protein antara remaja gizi lebih dan normal cenderung sama. Hal ini disebabkan protein yang dikonsumsi belum mernpunyai mutu protein yang tinggi (mengandung semua asam amino essensial dalam jumlah dan proporsi yang cukup), karena pertumbuhan dan penambahan otot akan terjadi bila mutu protein itu komplit atau protein dengan nilai biologi tinggi yang mengandung semua jenis asam amino essensial dalam jumlah dan proporsi sesuai dengan keperluan pertumbuhan. Penyebab lain kemungkinan protein digunakan sebagai pengganti energi yang kurang, karena bila energi didalam tubuh terbatas maka sel terpaksa menggunakan protein untuk membentuk/ menghasilkan energi dan juga faktor genetik. Faktor-faktor yang menyebabkan terjadinya kegemukan adalah faktor genetik, kerusakan pada satu bagian otak, pola makan berlebih, jarang berolahraga, ketidakstabilan emosi dan faktor lingkungan (24).

Sebanyak $(58,5 \%)$ siswa yang tingkat kecukupan lemak yang lebih memiliki status gizi lebih. Hasil uji Chi-Square menunjukkan nilai $p$-value $=0,019(p<0,05)$, ini berarti bahwa Ada hubungan antara tingkat kecukupan asupan lemak dengan status gizi siswa SMA Negeri 86 Jakarta. Kemudian, diperoleh nilai $\mathrm{OR}=2,740$ yang berarti bahwa responden yang memiliki tingkat kecukupan lemak yang lebih berpotensi 2,740 kali lipat mengalami status gizi lebih. 
Lemak merupakan sumber energi paling padat, zat gizi ini menghasilkan 9 kalori untuk setiap gramnya yaitu 2,25 kali lebih besar energi yang dihasilkan oleh karbohidrat dan protein dalam jumlah yang sama. Lemak merupakan cadangan energi tubuh terbesar.Simpanan lemak tersebut berasal dari konsumsi salah satu atau kombinasi beberapa zat energi yaitu karbohidrat, lemak, dan protein (25). Hasil penelitian ini sejalan dengan penelitian yang dilakukan oleh Muchlisa (2013) mengatakan bahwa terdapat hubungan yang signifikan antara tingkat kecukupan lemak dengan status gizi(20). Penelitian di Amerika dan Finlandia menunjukkan bahwa kelompok dengan asupan tinggi lemak mempunyai risiko peningkatan berat badan lebih besar dibandingkan dengan kelompok yang asupan rendah lemak dengan OR 1,7. Penelitian lain menunjukkan peningkatan konsumsi daging akan meningkatkan risiko obesitas sebesar 1,46 kali (26). Keadaan ini disebabkan karena makan berlemak mempunyai rasa yang lezat sehingga akan meningkatkan selera makan yang akhirnya terjadi konsumsi yang berlebihan (27). Tubuh mempunyai kapasitas tak terhingga untuk menyimpan lemak. Kelebihan asupan lemak diiringi peningkatan oksidasi lemak sehingga sekitar 96\% lemak akan disimpan dalam jaringan lemak. Penumpukan lemak dalam tubuh dapat berakibat menambahnya berat badan (28).

Sebanyak $(63,6 \%)$ siswa yang tingkat kecukupan karbohidrat yang lebih memiliki status gizi lebih. Hasil uji Chi-Square menunjukkan nilai $\mathrm{p}$-value $=0,044(\mathrm{p}<0,05)$, ini berarti bahwa Ada hubungan antara tingkat kecukupan karbohidrat dengan status gizi siswa SMA Negeri 86 Jakarta. Kemudian, diperoleh nilai $\mathrm{OR}=2,722$ yang berarti bahwa responden yang memiliki tingkat kecukupan karbohidrat lebih yang lebih berpotensi 2,722 kali lipat mengalami status gizi lebih.

Karbohidrat merupakan zat gizi yang diperlukan tubuh dalam jumlah besar untuk menghasilkan energi atau tenaga.Pemenuhan kebutuhan karbohidrat terutama didapat dari makanan pokok atau nasi yang diporsi sendiri oleh responden. Sayangnya, banyak responden yang mengaku sedang mengurangi porsi makan nasi karena ingin mengurangi berat badan, namun responden mengaku sering konsumsi camilan manis seperti kue, atau biskuit, sehingga tingkat kecukupan karbohidrat responden tetap terpenuhi atau cukup. Asupan karbohidrat responden dapat mempengaruhi status gizi karena jumlah konsumsi karbohidrat dapat meningkatkan jumlah energi secara signifikan.Hasil penelitian ini sejalan dengan penelitian yang dilakukan oleh Nabila (2018) mengatakan bahwa terdapat hubungan yang signifikan antara tingkat kecukupan karbohidrat dengan status gizi(29).Sebagian besar responden memperoleh asupan karbohidrat dari konsumsi nasi.Terdapat responden yang mengkonsumsi 300 gram nasi dalam 1 kali makan. Menurut penuturan responden, jika konsumsi nasi kurang maka akan membuat responden lemas. Kegemukan dapat terjadi akibat konsumsi makanan yang melebihi angka kecukupan gizi. Seseorang yang mengonsumsi karbohidrat dalam porsi besar akan meningkatkan pengeluaran insulin, menambah penyimpanan lemak, dan meningkatkan level serum trigliserida. Kelebihan asupan tersebut akan disimpan di dalam otot atau lemak. Namun, jika terus menerus menumpuk dan berlangsung lama tentu saja akan menyebabkan kegemukan (30).

Sebanyak $(90,0 \%)$ siswa yang citra tubuh negatif memiliki status gizi lebih. Hasil uji Chi-Square menunjukkan nilai pvalue $=0,0001 \quad(\mathrm{p}<0,05)$, yang berarti bahwa Ada hubungan antara citra tubuh dengan status gizi siswa SMA Negeri 86 Jakarta. Kemudian, diperoleh nilai $\mathrm{OR}=30,214$ yang berarti bahwa responden yang memiliki citra tubuh negatif lebih beresiko 30,214 kali lipat mengalami status gizi lebih.

Citra tubuh pada umumnya dialami oleh mereka yang menganggap bahwa penampilan adalah faktor yang paling penting dalam kehidupan. Hal ini terutama terjadi pada usia remaja. Mereka beranggapan bahwa 


\section{Gorontalo Journal Health and Science Community}

Vol :4, No.1,April 2020

tubuh yang kurus dan langsing adalah yang ideal bagi wanita, sedangkan tubuh yang kekar dan berotot adalah yang ideal bagi pria (10).Citra tubuh negatif biasanya bertahan dalam jangka waktu yang lama. Sering sekali remaja merasa terlalu gemuk ataupun terlalu kurus dari ukuran yang sebenarnya, sehingga mereka ingin mengubah bentuk tubuhnya dengan cara diet ataupun olah raga yang berlebihan. Persepsi mengenai citra tubuh pada remaja dapat mengakibatkan implikasi negatif bagi kesejahteraan fisik dan psikologisnya (31).

Hasil penelitian ini menunjukkan bahwa responden yang memiliki citra tubuh negatif tidak hanya responden yang memiliki status gizi lebih, namun juga terjadi pada responden dengan status gizi normal yaitu sebanyak $12,9 \%$. Hal ini menunjukkan bahwa responden masih sering menganggap ukuran tubuhnya masih lebih besar dari ukuran sebenarnya padahal responden sudah memiliki tubuh yang ideal. Remaja dengan citra tubuh negatif yang memiliki pengetahuan gizi yang kurang cenderung kurang baik dalam memilih makanan yang mereka konsumsi sehingga penilaian negatif tentang citra tubuhnya akan mempengaruhi status gizinya. Mereka berpikir bahwa tubuh mereka tidaklah ideal, serta pemilihan makanan yang salah akan membuat mereka semakin sulit menentukan apakah status gizinya sudah dalam keadaan baik atau tidak (32). Penelitian lain juga menyatakan bahwa terdapat hubungan antara citra tubuh dengan status gizi (33).

\section{KESIMPULAN DAN SARAN}

\subsection{Kesimpulan}

Dari hasil analisis data dapat disimpulkan bahwa ada hubungan antara tingkat pengetahuan gizi seimbang, citra tubuh, tingkat kecukupan energi, lemak, karbohidrat dengan status gizi siswa SMA Negeri 86 Jakarta.

\subsection{Saran \\ Diharapkan semua siswa mulai memperhatikan asupan makanannya}

(konsumsi gizi seimbang, kurangi makanan berlemak) dan memantau berat badan. Diharapkan adanya pengukuran status gizi siswa dan pemeriksaan kesehatan secara rutin melalui program Usaha Kesehatan Sekolah (UKS). Pemantauan status gizi ini penting sebagai tindakan pencegahan agar siswa tidak terkena penyakit sebagai dampak dari status gizi lebih.

\section{UCAPAN TERIMA KASIH}

Peneliti mengucapkan terima kasih kepada pihak sekolah SMA Negeri 86 Jakarta serta pihak-pihak yang telah mendukung dan membantu dalam melaksanakan penelitian ini. Manuskrip ini telah diikutkan pada Scientific Article Writing Training (SAWT) Batch II, Program Kerja GREAT 4.1.e, Program Studi S1 Gizi, FIKES, Universitas Esa Unggul dengan dukungan fasilitator Dudung Angkasa, S.Gz., M.Gizi., RD; Khairizka Citra Palupi, S.Gz., M.Sc., dan Laras Sitoayu, S.Gz., M.K.M., RD. SAWT Batch II juga mendapat dukungan dana dari Universitas Esa Unggul.

\section{DAFTAR PUSTAKA}

1. WHO. Adolescenct Health; 2014.

2. Khomsan A. Peranan Pangan Dan Gizi Untuk Kualitas Hidup Jakarta: PT. Grasindo; 2004.

3. Brown J. Nutrition Through the Life Cycle; 2013.

4. Proverawati A. Permasalahan dan perubahan perilaku di kehidupan remaja Yogyakarta: Nuha Medika; 2010.

5. Hasdianah. Gizi pemanfaatan gizi, diet an obesitas Yogyakarta: Nuha Medika; 2014.

6. WHO. World Health Statistic ; 2011.

7. Balitbangkes. Riset Kesehatan Dasar (Riskesdas).; 2018.

8. Supariasa. Penilaian Status Gizi Jakarta: EGC; 2002.

9. Matz PE. Correlates Of Body Image Dissatisfaction Among Overweight Women Seeking Weight Loss. Journal Of Consulting And Clinical Psychology. $2002 ;:$ p. 70 . 
10. Germov J, Williams L. A Sociology of food \& Nutrition: The Social Appetite New York: Oxford University Press; 2004.

11. Christina. SA. Analisis Hubungan Body Image dan Pola Makan Terhadap Status Gizi Poltekkes Kemenkes Kupang. CHMK Health Journal. 2018;: p. 32-37.

12. Restiani. Hubungan citra tubuh, asupan energi dan zat gizi makro serta aktivitas fisik dengan status gizi lebih pada siswa SMP Muhammadiyah 31 Jakarta Timur Tahun 2012. Fakultas Kesehatan Masyarakat, Universitas Indonesia. 2012.

13. Bibilodi M, Pich J. Body image and eating pattern among adolescents. BMC Public Health. 2013;: p. (pp. 13(1104):1-10).

14. Meilani. Masalah Gizi Ganda pada Remaja Usia 15-19 Tahun. Journal of the Indonesian Medical Association. 2014;: p. Volum 64, No.1.

15. Bani A. Studi tentang persepsi mahasiswa tentang tubuh ideal dan hubungannya dengan upaya pencapaiannya. 2010.

16. Kementerian Kesehatan RI. Peraturan Menteri Kesehatan RI Nomor 2 Tahun 2020 Tentang Standar Antropometri Anak. Jakarta:; 2020.

17. Marihabe. Hubungan pengetahuan gizi seimbang dengan praktik gizi seimbang mahasiswa program studi pendidikan dokter angkatan 2013. FK Universitas SAM Ratulangi. 2013.

18. Syahrir. Remaja dan permasalahannya Jakarta: Gramedia; 2013.

19. Evans E.W JD,\&MA. The Role of Eating Frequency on Total Energy intake and Diet Quality in a low income, Racially Diverse sample of schoolchildren. Public Health Nutrition. 2015;: p. 18(3), 474-481.

20. Muchlisa. In Hubungan Asupan Zat Gizi Dengan Status Gizi Pada Remaja Putri Di Fakultas Kesehatan Masyarakat Universitas Hasanuddin Makassar Tahun 2013. Makassar: FKM UNHAS; 2013.

21. Devi N. Nutition and Food : Gizi untuk Keluarga Jakarta: Penerbit buku kompas; 2010.

22. Atika W,PMI,aKNH. Hubungan Antara Asupan Energi dan Zat Gizi Makro dengan Status Gizi pada Pelajar di SMP Negeri 13 Kota Manado. Jurnal Ilmiah Farmasi. 2015;: p. Vol. 4.
23. Rinanti O,S. Hubungan Asupan Zat Gizi Makro dan Pengetahuan Gizi Seimbang dengan Status Gizi Siswa-Siswi di SMP Muhammadiyah 1 Kartasura Surakarta: Universitas Muhammadiyah Surakarta; 2014.

24. Ramayulis , Lesmana LC. 17 Alternatif untuk Langsing Jakarta: Penebar Swadaya; 2008.

25. Almatsier S. Prinsip dasar Ilmu Gizi jakarta: gramedia pustaka umum; 2009.

26. Fukuda T. Obesity and Lifestyle. Asian Medical Journal. 2001;: p. vol 44: 97-102.

27. Kopelman. Obesity as a Medical Problem. NATURE. 2000;: p. 635.

28. Almatsier S. Prinsip Dasar Ilmu Gizi Jakarta: PT Gramedia Pustaka Utama; 2004.

29. Siwi N. Hubungan Asupan Karbohidrat, Lemak, dan Protein dengan Status Gizi (studi kasus pada pekerja wanita penyadap getah karet di perkebunan kalijompo jember). The Indonesian Jurnal Of Public Health. 2018.

30. Depkes RI. Pedoman Umum Gizi Seimbang. In. Jakarta: Departemen Kesehatan Republik Indonesia; 2002.

31. Kerner C,HL\&KD. Understanding Body Image in Physical Education: Current Knowledge And Future Directions. Eur. Phys. Educ. 2018;: p. 255-265.

32. Sa'diyah H. Pengaruh Citra Tubuh Terhadap Penyesuaian Diri Siswa-Siswi Kelas VII-VIII SMP NU Syamsuddin Malang. 2015.

33. Laus M. Body image dissatisfaction, nutritional status, and eating attitudes in adolescents. Acta Sci. Heal. Sci. 2013;: p. 243-247. 